\title{
Evaluation of Inclusive Education Program at Elementary Schools
}

\author{
Nuroel Tri Isna Wijaya ${ }^{1}$, Ruqaiyah ${ }^{2}$, Siti Zulaikha ${ }^{3}$ \\ DOI: 10.35445/alishlah.v13i3.907
}

\begin{tabular}{l}
\hline Article Info \\
\hline Keywords: \\
Evaluation of program; \\
Inclusive Education; \\
CIPP; \\
Elementary School
\end{tabular}

Keywords:

Evaluasi Program; Pendidikan Inklusif; CIPP; Sekolah Dasar

\begin{abstract}
The purpose of this study is to describe the program's effectiveness using a qualitative descriptive method by examining the context, input, process, and product of an inclusive education program at an elementary school in Palembang. Interviews, observation, documentation, questionnaires, and focus group discussions are all used to collect data. The principal, deputy principal for curriculum, the education office of Palembang city, class teachers, the South Sumatera Provincial Education Office, and Guardians of Special Needs Students served as informants for the research. The findings indicated that the contextual evaluation did not consider the program's needs and objectives. There are flaws in the way organizers and implementers analyze program needs in terms of context. The outcome of the input evaluation indicates that it is not adhering to the components of inclusive education implementation. The process evaluation revealed that the performance adhered to child-friendly schools in some areas, most notably in implementing the teaching and learning process. While some product evaluation results have been successful, critical considerations must be significantly improved, beginning with program planning, monitoring, and reporting. In general, the program evaluation components indicate that schools have demonstrated a high level of commitment and consistency in implementing the program since 2013. This needs to be improved by the guidelines for inclusive education implementation.
\end{abstract}

\begin{abstract}
Abstrak
Penelitian ini mendeskripsikan efektivitas program melalui context, input, proses dan produk program pendidikan inklusif di Sekolah Dasar Palembang dengan metode deskriptif kualitatif. Teknik pengumpulan data yaitu wawancara, observasi, dokumentasi, angket dan diskusi kelompok terfokus. Informan penelitian yaitu Kepala Sekolah, Wakil Kepala Sekolah Bidang Kurikulum, Dinas Pendidikan Kota, Guru Kelas, Dinas Pendidikan Provinsi serta wali murid PDBK. Hasil penelitian menunjukkan evaluasi kontkes belum sesuai dengan kebutuhan dan tujuan penyelenggaraan program. Dalam hal ini terdapat kelemahan dalam menganalisis kebutuhan program oleh penyelenggara dan pelaksana. Hasil evaluasi input menunjukan tidak sesuai dengan komponen penyelenggaraan pendidikan inklusif. Pada hasil evaluasi proses implementasinya sebagian telah sesuai dengan konsep sekolah ramah anak terutama pada aspek pelaksanaan KBM. Hasil evaluasi produk sebagian telah berhasil dengan pertimbangan perlu dilakukan perbaikan secara serius dimulai dari perencanaan, pengawasan dan pelaporan program. Secara keseluruhan komponen evaluasi program menunjukan sekolah memiliki komitmen yang tinggi dan sikap konsisten dalam menjalankan program sejak
\end{abstract}

\footnotetext{
${ }^{1}$ Universitas Negeri Jakarta, Jakarta, indonesia

Email: nuroelwijaya@yahoo.com

${ }^{2}$ Universitas Negeri Jakarta, Jakarta, Indonesia

3 Universitas Negeri Jakarta, Jakarta, Indonesia
} 
tahun 2013 dan perlu ditingkatkan sesuai pedoman penyelenggaraan pendidikan inklusif.

\section{INTRODUCTION}

All children have the right to an education. A child is a one-of-a-kind individual who becomes a trustee and a gift from God Almighty, endowed with dignity, dignity, and righteousness as a complete human being. The person's rights as a whole have implications for the need for protection and legal safeguards for all children, one of which is the right to education (Kustiawan, 2013:13). Indeed, the most marginalized group in education is children with disabilities. Children with disabilities face a heightened risk of discrimination and rejection. Among the reasons for refusal is that 'not everyone can see and accept children's differences. What should be referred to as uniqueness can be viewed as a problem that needs to be separated and avoided. According to Ellison, invisibility occurs when a person loses their human characteristics due to others viewing him through a prejudiced lens. This bias or definition based on physical, mental, or social differences is the source of rejection and discrimination directed at children with special needs (Smtih, 2018: 32).

According to Ministry of Education and Culture documents published in 2019, the number of people with disabilities (BPS Projection) is expected to reach 6,002,500 people (2.45 per cent) of the approximately 245 million Indonesians. The total population of school-aged disabled people is $1,500,625$ people or $25 \%$ of the total population of disabled people. According to BPS calculations, the number of students with disabilities enrolled in SLB and inclusive schools is estimated to be $16 \%$ of total ABK, with 134,045 ABK enrolled in special schools and 1-4,931 ABK enrolled in inclusive schools. As a result of the explanation above, it is clear that up to 84 per cent of school-aged individuals with disabilities or children with special needs have not received educational services. Meanwhile, according to 2019 PLB statistics, Indonesia has 2212 SLB and 180 SDLB with a total GDPK of 113,826 and as many as 1914 PDBK experiencing school dropouts (Kemendikbud, 2019:2).

As a country that protects the rights of all of its citizens, Indonesia understands the importance of education that does not discriminate against the rights of children. If the educational system fails to recognize this, the ideals of educating the nation's future will be undermined. We require a system of education accessible to all children (education for all). This type of system is referred to as inclusive education. It is an approach that seeks to transform the education system by removing barriers that can prevent individuals from fully participating in education while also providing them with support services (Keller, 2013: 29).

This means that a professional attitude and a commitment to the local context are essential for inclusive education to succeed in practice (Kemal \& Hasibuan, 2017). The inclusive education program in Indonesia's various regions is based on this principle. From government declarations to actual implementation, inclusive education has evolved into a nationwide movement that calls for establishing at least one inclusive school in every district. Several provincial and municipal governments have claimed to be inclusive cities until this point. As an example, we'll talk about South Sumatra. South Sumatra's government organized an inclusive education program in every city and district using the inclusive school program.

Throughout South Sumatra, Palembang serves as a barometer for inclusive education due to the efforts of the Palembang City Government, through the Palembang City Education Office and the South Sumatra Provincial Education Office to track and report on the development of inclusive school programs. Online news sources report that the Kompas and Republika newspapers as well as local newspapers such as the Haluan Sumatera and Palembang Pos, are actively involved in reporting on the development of inclusive schools in Palembang. On this basis, the Palembang City Education Office stated that it will: increase the number of inclusive schools, particularly at the elementary school level, to broaden the reach of inclusive service programs. According to the findings of observations made by researchers between March 20 and April 1, 2019, there is a discrepancy between reporting the program's success and its implementation in the field. In its performance, not 
all of the schools named in the decree and reported in the news are implementing the inclusive education program.

No students with special needs were registered at four out of the five inclusive schools represented by the main informant, and the local government did not support the inclusive education program. As observed, one of the elementary schools at Palembang consistently implements the program. It has been implementing an inclusive school program since 2013 and has even been chosen as a pilot for national inclusive education, which was confirmed by the principal's interview results. However, until this year, the local government, through its relevant agencies, has not evaluated the program. According to Arikunto and West Java (2009:22), the program consists of actions to implement the policy. To know-how and to what extent policies can be implemented, a program must have been evaluated. The program's effectiveness, whether the goals are met, whether the program is implemented according to standard guidelines, and the urgency to expand the number of schools participating if many schools are no longer participating cannot be known by decision-makers. Researchers in program evaluation research are concerned about this. The inclusive education program has many interconnected components, so an appropriate evaluation model is needed to see the whole. The CIPP (Context, Input, Process, Product) model is appropriate until the problem is solved by formulating the problem.

\section{METHOD}

The study took place at SDN 30 Palembang. The qualitative descriptive method was used in this study. The design is based on the September 2019 CIPP model. This inclusive school was chosen based on the results of a pre-observation in March 2019, as well as on the researchers' ability and permission from schools willing to participate in the research, to ensure that the findings of this study are not generalizations from all-inclusive schools in Palembang and South Sumatra. According to the general guidelines for implementing inclusive education, the program's implementation is composed of the principal, deputy for curriculum, and teachers, as well as supporting informants such as representatives from the City and Provincial Education Offices and parents of GDPK students. Interviews, documentation, observation, focus group discussions, and questionnaires were used to collect data. Interview guidelines, observation sheets, documentation sheets, questionnaire sheets, field notes, and FGD guidelines were used as instruments.

To ensure the accuracy of the data, the researchers used a questionnaire. The data analysis technique is qualitative, consisting of data reduction, visualization, and conclusion/verification. Credibility (internal validity), transferability (external validity), dependability (reliability), and confirmability are all included in the data validity test (objectivity). Technical triangulation and source triangulation are the two triangulation techniques used. Triangulation is a technique that utilizes participatory observation, interviews, and documentation of the same resource concurrently. They compared the level of expertise of data and information obtained from various sources, such as interviews and observations, interviews and documentation, and interviews and FGDs.

\section{FINDINGS AND DISCUSSION}

SDN 30 Palembang runs an inclusion program based on mapping and observations and based on appointments from the Regional Government through the South Sumatra Provincial Education Office. It is also based on the history and geography of schools that long received the GDPK. Here's an overview: 


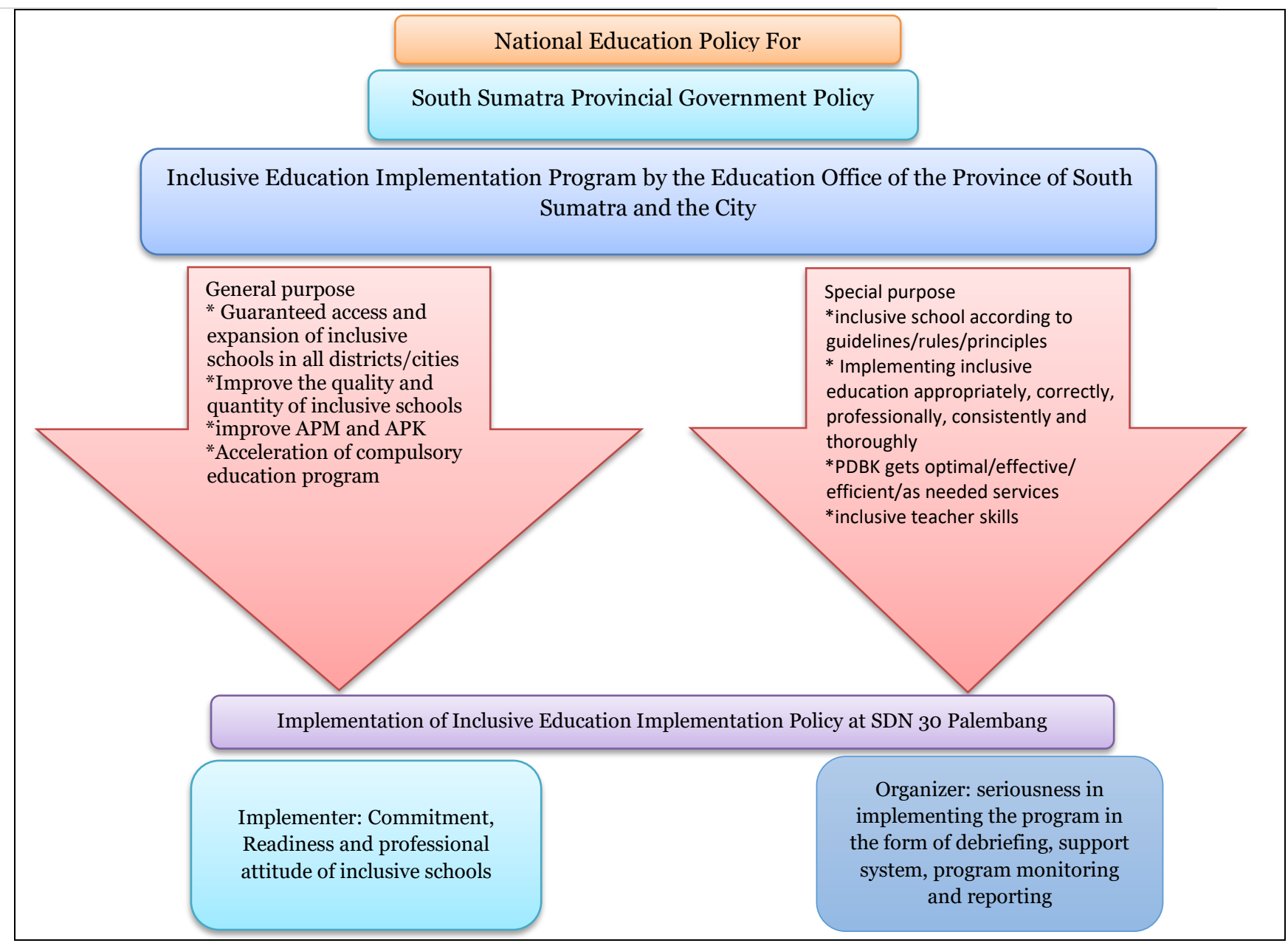

\section{Figure 1. Objectives of Implementing Inclusive Education Programs}

The study results showed that in the context component, three aspects are evaluated, including the background, objectives, and needs analysis of the inclusive education program at SDN 30 Palembang. From the three aspects, the results show that two aspects are not appropriate, namely the purpose and analysis of program needs, while the background aspect is partially by the note that there is an implementation mechanism that the program organizers have not prepared. This is in line with what was Loreman (2013) revealed by that this study details the results of a review of the academic and public sector literature on the measurement of inclusive education in large systems. It highlights some of the results drawn from the international literature on inclusion that may indicate the presence and quality of inclusive education to develop a set of outcomes. This is also expressed by Murniati et al. (2018) in their research that implementing inclusive education in schools is not going well. Furthermore, supervision, monitoring and development of inclusive education in inclusive schools.

In the input component, seven aspects are evaluated showing results, namely school management Mostly inappropriate, GDPK acceptance system mostly inappropriate, inclusive teacher competence is not appropriate, the role of parents of GDPK students is appropriate, the curriculum is mostly inappropriate, facilities and infrastructure are not appropriate, and financing shows inconsistent results. This is in line with what Ediyanto et al. (2018) expressed as a need for an Education and Training Program for the Development of Special Guidance for Teachers. Guidance and can contribute to increasing the special competence of supervisory teachers. Hopefully, this program can be implemented for the success of the Indonesian nation education in general and Indonesian Inclusive Education in particular. Meanwhile, Marimuthu \& Cheong (2015) also stated that inclusive education requires well-equipped, knowledgeable and competent teachers who can 
cultivate the required values, confidence and support in disabled students, thus preparing them to become capable citizens.

In the process component, four aspects are evaluated, including planning inclusive education programs that are not appropriate. The evaluation results of the implementation of inclusive learning are by the concept of child-friendly schools. The process assessment and assessment of GDPK learning outcomes are not appropriate. The monitoring and evaluation of the program are most appropriate. In the product component, four aspects are evaluated, including the attitude of normal students towards the GDPK showing appropriate results, the success of adaptation and socialization of the GDPK has been appropriate, the development of the number of GDPK during the running program showing inappropriate results and the absence of reporting on the inclusive school program proves that it does not comply with the guidelines. This is also expressed by Davis \& Vaisey (1997), who also revealed that The evidence shows serious deficiencies in adopting CPGs in practice. Future implementation strategies must overcome this failure by understanding the forces and variables influencing practice and using methods that are practice- and community-based rather than didactic. Ametepee \& Anastasiou (2015) also revealed that a Strategic Education Plan is needed to evaluate progress in special and inclusive education

\section{CONCLUSION}

The context component is not by the program needs and objectives of implementing inclusive education programs. It can be said that there is a context component where there are weaknesses, especially both program organizers and program implementers who have not been able to compile a program needs analysis so that it is relevant to the objectives that were initiated from the start. The evaluation results of program inputs at elementary schools in Palembang are not by the components of the implementation of the inclusive education program. In this aspect, very significant improvements are needed in 3 aspects, namely the human resource aspect, especially in efforts to increase the competence of inclusive teachers, aspects of the support system and aspects of program financing that need to be clarified. Meanwhile, the evaluation process results showed that the implementation of inclusive education was by the guidelines, especially in implementing a childfriendly learning process. Furthermore, in program implementation results or product evaluation, some have succeeded with important considerations that great improvements need to be made, especially in program administration and reporting. Before increasing the number of inclusive schools, it would be more appropriate to compile and stipulate laws and regulations or regional regulations/regional heads/mayor regulations as a legal umbrella for program implementation. The umbrella of applicable laws and regulations is important to ensure, ensure the performance and availability of programs starting from the aspect of the financing, which has always been a classic problem, supporting programs to increase teacher competency that is inclusive cannot be implemented if only a few teachers are trained. The model of inclusive teacher training activities is necessary. It was improved, especially in coordination with related parties such as special schools, experts and training experts on inclusive education. In addition, the government is obliged to provide GPK in schools that have been designated as inclusive schools.

\section{REFERENCES}

Arikunto, S., \& Jabar, C.S.A. (2009). Evaluasi Program Pendidikan: Pedoman Teoritis Praktis Bagi Mahasiswa dan Praktisi Pendidikan. Jakarta: Bumi Aksara.

Amatepee, Lawrence Kofi \& Anastasiou, Dimitris. (2015). Special and Inclusive Education in Ghana: Status and Progress, Challenges and Implication. International Journal of Educational Development, 41 (3) pp. 143-152. https://doi.org/10.1016/j.ijedudev.2015.02.007

Amstrong, F. (2003). Inclusive Education: Cross-Cultural Perspectives: Space Out, Policy, Difference and the Challenge of Inclusive Education. New York: Kluwer Academic Publishers.

Chen, H. T. (2005). Pratical Program Evaluation: Assessing and Improving Planning, Implementation and Effectiveness. USA: Sage Publications, Inc. 
Dash, N. (2006). Inclusive Education: For Children With Special Needs. India: Atlantic.

Davis, D.A \& Vaisey, Taylor. (1997). Translating Guidelines Into Practice: A Systematic Review of Theoretic Concepts, Practical Experience and Research Evidence in The Adoption of Clinical Practice Guidelines. Canadian Medical Association Journal, 157 (4), pp. 408-416.

Ediyanto., Mulyadi, Agus.., Supriyatna, Agus., Kawai, Norimune. The Education and Training Program Guideline for Special Guideline Teacher Competence Development in Indonesian Inclusive School. IJDS: Indonesian Journal of Disability Studies, 5 (2). http://dx.doi.org/10.21776/ub.IJDS.2018.005.02.15

Handayani, T., \& Rahadian, A.S (2013). Peraturan Perundangan dan Implementasi Pendidikan Inklusif. Jurnal Masyarakat Indonesia, (39) 1. https://doi.org/10.14203/imi.v39i1.307

Haryono., S. A., \& Widiastuti, S. (2015). Evaluasi Pendidikan Inklusif Bagi Anak Berkebutuhan Khusus (ABK) di Provinsi Jawa Tengah. Jurnal Penelitian Pendidikan, (32) 2. 10.15294/jpp.v32i2.5057

Keller. (2013) . Prosedur Operasional Standar dan Modul Pelatihan Pendidikan Inklusif Berbasis Sekolah. Jakarta: Hellen Keller Internasional Indonesia.

Kemal, Isthifa, \& Hasibuan, Rossy Anggelia. (2017). Manajemen Kewirausahaan Melalui Strategi Berbasis Sekolah Di Islamic Solidarity School. Jurnal Akuntabilitas Manajemen Pendidikan, 5 (1), pp. 71-81. https://doi.org/10.21831/amp.v5i1.11550

Kemendikbud. (2018a). Statistik PLB. Jakarta: Pusat Data dan Statistik Pendidikan dan Kebudayaan Diakses dari https://repositori.kemendikbud.go.id/5748.

Kemendikbud. (2011(. Pedoman Umum Penyelenggaraan Pendidikan Inklusif: Sesuai Permendiknas No. 70 Tahun 2009. Jakarta: Direktorat PPK-LK. Diakses dari https://www.wcrobd.com/documents/242077455/pedoman-umum-pendiidkan-inklusif2011-pdf

Kemendikbud. )2016). Gambaran SekolahInklusif di Indonesia: Tinjauan Sekolah Menengah Pertama. Jakarta: Pusat Data dan Statistik Pendidikan dan Kebudataan. Diakses dari https://publikasi.data.kemendikbud.go.id/uploadDir/isi_14Dof106-F4EE-486BA74F84A191B4AD25.pdfKi

Krik, S. G., \& Coleman, M. R. (2009). Educating Exceptional Children. Twelfth Edition. New York: Houghton Mifflin.

Kamenopoulou, L. (2017). Special Issue on Inclusif Education An Introduction. Athens Journal of Education, November 2017, 4, (4). https://www.athensjournals.gr/education/2017-4-4Introduction.pdf

Kustawan, D. (2013). Manajemen Pendidikan Inklusif: Kiat Sukses Mengelola Pendidikan Inklusif di Sekolah Umum dan Kejuruan. Jakarta: Luxima Metro Media.

Langbein, L. (2012). Public Program Evaluation: A Statistical Guide, $2^{\text {nd }}$ Edition. New York: Rouledge.

Loreman, Tim. (2012). Measuring Inclusive Education Outcomes in Alberta, Canada. International Journal of Inclusive Education, $18 \quad$ (5), $\quad$ pp. 459-483. https://doi.org/10.1080/13603116.2013.788223

Lukitasari, S.W., Sulasmono, B.S., \& Iriani, A. (2017). Evaluasi Implementasi Kebijakan Pendidikan Inklusi. Kelola Jurnal Manajemen Penndidikan, 4 (2). https://doi.org/10.24246/j.jk.2017.v4.i2.p121-134

Marimuthu, Susila \& Cheong, Loh Sau. (2015). Inclusive Education for Social Transformation. Procedia-Social and Behavioral Sciences, 172 (January), pp. 317-322. https://doi.org/10.1016/j.sbspro.2015.01.370

Mitchell, D. (2014). What Really Works in Special and Inclusive Education: Using Evidence-Based Teaching Strategie, $2^{\text {nd }}$ Edition. New York: Routledge. 
Murniati, Ar., Usman, Nasir., ZA, Thabrani., Syahril. ( 2018). Inclusive $\quad$ Education Management in State Primary Schools in Banda Aceh. Advanced Science Letters, 24 (11), pp. 8313-8317. https://doi.org/10.1166/asl.2018.12549

Patton, M. Q. (2002). Qualitative Research \& Evaluation Methods, $3^{\text {rd }}$ Edition. London: Sage Publications.

Smith, J. D. (2018). Sekolah Untuk Semua: teori dan Implementasi Inklusi. Bandung: Nuansa Cendikia.

Stufflebeam. D.L., \& Coryn, C. LS. (2014). Evaluation Theory, Models \& Applications. San Fransisco: Jossey-Bass.

Stubbs, S. (2002). Inclusive Education: Where There Are Few Resources. Uk: The Atlas. Alliance.

Sukmadinata, N. S. (2006). Metode Penelitian Kualitatif . Bandung: Graha Aksara. 